\title{
ANALISIS PENGAWASAN PENGELUARAN BARANG PADA TOKO BEBAS BEA DALAM KOTA (DUTY FREE SHOP) DALAM UPAYA MENGAMANKAN PENERIMAAN PAJAK DI KANTOR PENGAWASAN DAN PELAYANAN BEA DAN CUKAI TIPE MADYA PABEAN A JAKARTA
}

\author{
Pebriana Arimbhi ${ }^{1}$, Edy $^{2}$, Gandri Narandu \\ Email: pebrianasusanto@yahoo.com ${ }^{1}$, edykusuma37@yahoo.co.id ${ }^{2}$ \\ Institut Ilmu Sosial dan Manajemen STIAMI
}

\section{ARTICLE INFO}

Keywords:

Supervision,

Customs,

Duty Free Shop

\section{ABSTRACT}

\begin{abstract}
A Thesis discussed supervision to their expense of goods on one of the tweeps facilities the store is free the duties is under office customs jakarta, namely pt sj indonesia / lotte duty free in a bid to secure tax revenue.The purpose of he did this study is to find a monitoring system to their expense goods applied to PT SJ Indonesia / Lotte Duty Free in an effort to tax revenues and the obstacles with respect to the supervision. The research is based on the qualitative research descriptive by applying a technique the collection of data in the form of the objective of the interview and secondary data.The results of the interviews and the data on after that it is processed and analyzed in order to understand the supervision to their expense of goods which will be applied is he would do to PT SJ Indonesia / Lotte Duty Free in a bid to secure the country tax receipts. The result of this research, the author concluded that the supervision to their expense goods applied to PT SJ Indonesia / Lotte Duty Free in a bid to secure tax revenue has been running in accordance with the rules applied apply. But, its implementation happened obstacles is internal, like a coordination between supervision office, and obstacles which are external, as an opportunity used company related for committing a foul and have not the construction of a technological system and information centralized.
\end{abstract}

\section{INTRODUCTION}

Institusi kepabeanan di Indonesia, Direktorat Jenderal Bea dan Cukai (DJBC) memiliki 4 (empat) tugas utama yaitu sebagai revenue collector, community protector, trade facilitator dan industrial assistance. DJBC dalam menjalankan keempat tugas utama tersebut, dituntut untuk memberikan pelayanan prima kepada stakeholder kepabeanan dan cukai demi peningkatan taraf perekonomian nasional. Namun, di sisi lain DJBC juga dituntut untuk memberikan pengawasan yang efektif dan efisien dalam rangka penegakan hukum di bidang kepabeanan dan cukai, serta demi terpenuhinya hak-hak negara yang pada konteks ini adalah penerimaan negara. Pada salah satu tugas utama DJBC yaitu trade facilitator, DJBC dituntut untuk membuat suatu hukum kepabeanan yang dapat mengantisipasi perkembangan dalam masyarakat dalam rangka memberikan pengawasan dan pelayanan yang lebih cepat, lebih baik, dan lebih murah. DJBC juga diharapkan dapat memberikan fasilitas perdagangan antara lain peningkatan kelancaran arus barang dan perdagangan sehingga dapat menekan ekonomi biaya tinggi yang pada akhirnya akan menciptakan iklim perdagangan yang kondusif. Salah satu fasilitas yang diberikan oleh Direktorat Jenderal Bea dan Cukai demi melaksanakan tugas utama sebagai trade facilitator yaitu DJBC memberikan fasilitas berupa Tempat Penimbunan Berikat. Tempat Penimbunan Berikat adalah bangunan, tempat atau kawasan yang memenuhi persyaratan tertentu yang digunakan untuk menimbun, mengolah, memamerkan dan / atau menyediakan barang untuk dijual dengan mendapatkan penangguhan Bea Masuk dan Pajak Dalam Rangka Impor. Tempat Penimbunan Berikat dibagi menjadi tujuh, yaitu Kawasan Berikat, Gudang Berikat, Tempat 
Penyelenggaraan Pameran Berikat, Tempat Lelang Berikat, Kawasan Daur Ulang Berikat, Pusat Logistik Berikat, dan Toko Bebas Bea. Pada Skripsi ini, penulis akan membahas mengenai Toko Bebas Bea.

Dasar hukum pengawasan yang dilakukan oleh Direktorat Jenderal Bea dan Cukai (DJBC) pada Tempat Penimbunan Berikat (TPB) adalah Undang-Undang Nomor 17 tahun 2006 tentang perubahan atas UndangUndang Nomor 10 tahun 1995 tentang Kepabeanan. Undang-Undang ini menempatkan kewajiban pabean sebagai kewajiban kewarganegaraan yang mencerminkan peran serta anggota masyarakat dalam menghimpun dana melalui pembayaran bea masuk. Perundang-undangan ini merupakan bagian dari hukum fiskal yang harus dapat menjamin perlindungan kepentingan masyarakat, kelancaran arus barang, penerimaan bea masuk yang optimal, dan dapat menciptakan iklim usaha yang dapat mendorong perkembangan nasional.

Toko Bebas Bea merupakan salah satu dari 7 (tujuh) Tempat Penimbunan Berikat yang berfungsi untuk menimbun barang asal impor dan / atau dari dalam daerah pabean untuk dijual kepada orang tertentu. Arus lalu lintas barang dan orang dari satu negara ke negara lain yang semakin meningkat menyebabkan peran dari Toko Bebas Bea juga ikut meningkat. Toko Bebas Bea merupakan bagian dari Tempat Penimbunan Berikat yang pemasukan barangnya mendapat perlakuan pembebasan Bea Masuk dan/atau tidak dipungut Pajak Dalam Rangka Impor berdasarkan Peraturan Pemerintah Nomor 85 Tahun 2015 tentang Perubahan Atas Peraturan Pemerintah Nomor 32 Tahun 2009 tentang Tempat Penimbunan Berikat dan Peraturan Menteri Keuangan Nomor 207/PMK.04/2017 yang baru saja tahun ini diterbitkan menggantikan Peraturan Menteri Keuangan Nomor 37/PMK.04/2013 tentang Toko Bebas Bea. Barang yang dimasukkan ke Toko Bebas Bea merupakan barang yang belum dibayar Bea Masuk, Cukai, dan / atau Pajak lainnya sehingga harus dilakukan pengawasan oleh Direktorat Jenderal Bea dan Cukai, dan peraturan mengenai tatalaksana terkait Toko Bebas Bea diatur dalam Peraturan DirekturJenderal Bea danCukai PER-19/BC/2013.

Toko Bebas Bea (TBB) atau Duty Free Shop adalah fasilitas pembebasan bea masuk dan pajak - pajak lainnya yang berasaskan domisili, yaitu pengenaan pajak berdasarkan tempat tinggal (domisili) Wajib Pajak dengan alasan bahwa sopan santun internasional (International Fatsoen) mengajarkan adalah tidak etis memungut pajak atas warga negara atau bangsa asing oleh sebab itu berlaku asas timbal balik (reciprocity).

Dikenal ada dua jenis TBB yaitu TBB Dalam Kota (downtown) dan TBB pada pelabuhan udara maupun laut. Secara umum, TBB yang diawasi oleh Kantor Pengawasan Dan Pelayanan Bea Dan Cukai Tipe Madya Pabean A Jakarta adalah TBB Dalam Kota (downtown). Toko Bebas Bea (TBB) Dalam Kota merupakan TBB yang berada di luar Kawasan Pabean pada bandara internasional maupun pelabuhan laut utama. TBB ini melayani penjualan bagi anggota korps diplomatik dan tenaga ahli badan internasional yang sedang bertugas di Indonesia, serta orang/turis asing yang akan pergi ke luar Daerah Pabean.

Instrumen utama pengawasan atas barang-barang yang dijual pada TBB Dalam Kota adalah Kartu Kendali untuk penjualan bagi anggota korps diplomatik dan tenaga ahli badan internasional, serta paspor dan tiket keberangkatan untuk penjualan bagi orang/turis asing. Hanya pemegang Kartu Kendali dan orang yang tertera dalam paspor dan tiket yang berhak melakukan transaksi pembelian di TBB Dalam Kota ini, tidak dapat diwakilkan.

Kartu Kendali dikeluarkan oleh Direktur Fasilitas atas nama Direktur Jenderal Bea dan Cukai, atas permohonan dari orang yang berhak mendapatkan fasilitas tersebut berdasarkan rekomendasi dari instansi terkait. Sementara itu, pengawasan atas TBB Dalam Kota merupakan tanggung jawab KPPBC yang wilayah kerjanya mencakup lokasi TBB Dalam Kota tersebut.

Gambar I.1 Grafik Penjualan Minuman Mengandung Etil Alkohol (MMEA) pada TBB di bawah pengawasan KPPBC TMP A Jakarta Periode Tahun Januari 2017 s.d Juni 2017

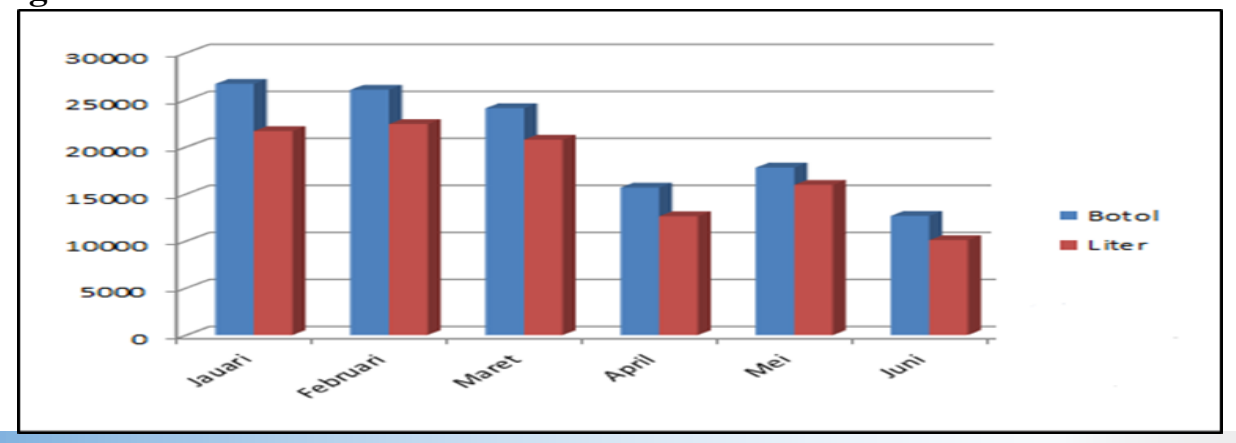

Pebriana Arimbhi, et.al (Analisis Pengawasan Pengeluaran Barang Pada Toko Bebas Bea...) 


\section{Sumber : Seksi Pelayanan dan Kepabeanan Cukai (PKC) KPPBC TMP A JAKARTA}

Kartu Kendali berikut lembar kontrol kuotanya, database, serta teknik pengawasan atas TBB Dalam Kota saat ini belum terintegrasi dan terotomasi dalam satu sistem. Demikian juga pengawasan atas keharusan pemegang Kartu Kendali sendiri yang harus melakukan transaksi pembelian yang belum ada. Sementara itu, WCO dalam rekomendasinya mengenai TBB pada tahun 1960 telah mempertimbangkan bahwa TBB secara umum dan TBB Dalam Kota khususnya mengandung risiko akan penyimpangan impor tingkat tinggi. Oleh karena itu, dipandang perlu untuk dilakukan penelitian lapangan dan kajian mengenai implementasi pengawasan dan pelayanan TBB Dalam Kota.

Pengawasan dilakukan dimulai dari pemasukan, pengelolaan, sampai pengeluaran barang ke dan/atau dari Toko Bebas Bea. Pengelolaan Toko Bebas Bea harus dilaksanakan berdasarkan ketentuan-ketentuan kepabeanan agar dapat berguna secara optimal, sedangkan pengawasan terhadap pemasukan dan pengeluaran barang impor dilakukan dengan tujuan memeriksa kesesuaian antara dokumen pemberitahuan dengan fisik barang. Namun, dalam pelaksanaannya masih terdapat beberapa kekurangan dalam pengawasan yang dilakukan oleh KPPBC TMP A Jakarta terhadap Toko Bebas Bea.

Adanya kendala dalam hal pengawasan tersebut dikarenakan seperti jumlah Toko Bebas Bea yang cukup banyak di Jakarta, ketidak lengkapan database Kartu Kendali yang dimiliki oleh KPPBC TMP A Jakarta yang dimana Kartu Kendali tersebut digunakan oleh Anggota Korps Diplomatik untuk mengeluarkan Barang dari Toko Bebas Beajuga menjadi salah satu masalah yang dihadapi oleh KPPBC TMP A Jakarta. Sedangkan database lengkap hanya dimiliki oleh Direktorat Fasilitas yang menyebabkan tidak efektifnya pengawasan yang dilakukan oleh KPBBC TMP A Jakarta apabila harus terlebih dahulu meminta database dari Direktorat Fasilitas untuk dapat melakukan pelayanan pemeriksaan barang yang pada akhirnya akan memakan waktu lebih lama, dan masalah tersebut dapat dijadikan sebagai modus oleh Anggota Korps Diplomatik untuk dapat mengeluarkan BKC khususnya MMEA melebihi batas maksimal yang dapat dikeluarkan sesuai dengan ketentuan yang berlaku. Lemahnya pengawasan juga disebabkan karena adanya perbedaan waktu operasional Gudang Penimbunan Toko Bebas Beadan jam kerja pegawai KPPBC TMP A Jakarta, terutama pada hari Sabtu ketika intensitas kegiatan gudang khususnya pada pengeluaran barang dalam kondisi tinggi namun bukan merupakan jam kerja pegawai.

Atas dasar hal tersebut, penulis menemukan beberapa permasalahan yang timbul dalam hal pengawasan pada Toko Bebas Bea. Namun, penulis mencoba memfokuskan penelitan pada salah satu Toko Bebas Bea yang, berada di bawah pengawasan Kantor Pengawasan dan Pelayanan Bea Cukai Tipe Madya Pabean A Jakarta yaitu PT SJ Indonesia.

Fenomena dalam penelitian ini adalah adanya pelanggaran dan potensial pelanggaran yang dilakukan oleh pengguna fasilitas kepabeanan dalam hal ini Toko Bebas Bea sehingga mengakibatkan hilangnya penerimaan pajak yang seharusnya dikenakan. Hal tersebut menunjukkan bahwa ada pengguna fasilitas kepabenanan dalam hal ini Toko Bebas Bea menyalahgunakan fasilitas kepabenan yang diberikan sehingga berdampak terhadap penerimaan pajak yang terhutang (ditangguhkan) yang mengakibatkan kerugian negara sebesar Rp 312.014.000,00 pada Kantor Pengawasan dan Pelayanan Bea Cukai Tipe Madya Pabean A Jakarta.

Tabel I.1 Rincian Nominal Kerugian Negara Akibat Ketidakpatuhan Wajib Pajak (TokoBebas Bea)

\begin{tabular}{|c|c|c|}
\hline Pungutan Negara & Nilai & Alasan Pelanggaran \\
\hline Bea Masuk & Rp. 103.832 .000 & \multirow{6}{*}{$\begin{array}{l}\text { Perusahaan TBB tidak dapat } \\
\text { mempertanggungjawabkan barang } \\
\text { yang seharusnya berada di TBB } \\
\text { yang bersangkutan }\end{array}$} \\
\hline Cukai & Rp 139.000 & \\
\hline PPN & Rp 60.295.000 & \\
\hline PPnBM & 0 & \\
\hline PPh Pasal 22 & Rp 43.916.000 & \\
\hline Denda & Rp 103.832.000 & \\
\hline Jumlah Tagihan & Rp 312.014.000 & \\
\hline
\end{tabular}

Sumber : Seksi Pelayanan dan Kepabeanan Cukai (PKC) KPPBC TMP A Jakarta 
Salah satu upaya yang dilakukan oleh Kantor Pengawasan dan Pelayanan Bea Cukai Tipe Madya Pabean A Jakarta dalam rangka mengamankan penerimaan pajak adalah peningkatan sistem pengawasan atas penyalahgunaan fasilitas terhadap pembelian oleh orang yang tidak berhak dan jumlah pembelian melebihi batas.

Tabel I.2 Orang yang berhak membeli di TBB Dalam Kota

1. Anggota korps diplomatik yang bertugas di Indonesia suami/istri

2. Pejabat / tenaga ahli yang bekerja pada badan internasional yang memperoleh kekebalan diplomatic beserta suami/istri

3. Orang yang akan keluar daerah pabean (penyerahan barang di TBB yang sama yang berlokasi di bandara / pelabuhan utama )

Sumber : Pasal 14 PMK No 204/PMK.04/2017 tentang Toko Bebas Bea

Terkait pengawasan pengeluaran barang pada toko bebas Dalam Kota (Duty Free Shop) dilakukan berdasarkan manajemen resiko. Dalam hal Pengusaha TBB terbukti melakukan pelanggaran maka diwajibkan membayar bea masuk yang terutang dan dikenakan sanksi administrasi berupa denda, pembekuan, maupun pencabutan izin sebagaimana diatur dalam Peraturan Menteri Keuangan Nomor 37/PMK.04/2013 tentang Toko Bebas Bea. Upaya lainnya yang dilakukan oleh Direktorat Jenderal Bea dan Cuka idalam rangka mengamankan penerimaan pajak adalah dengan mengganti peraturan - peraturan terkait Toko Bebas Bea yaitu PMK maupun Per Dirjen yang telah ada sebelumnya.

Secara umum pengeluaran barang pada pada toko bebas Dalam Kota (Duty Free Shop) dapat dilakukan dengan tujuan sebagai berikut:

a. pengeluaran sebagaimana dimaksud dalam Tabel I.2

b. ke gudang berikat, dalam hal barang retur/reject;

c. ke tempat lain dalam Daerah Pabean, dalam hal barang retur/reject;

d. Toko Bebas Bea lainnya;

e. diekspor kembali; dan/atau

f. dimusnahkan di bawah pengawasan Pejabat Bea dan Cukai.

Tulisan ini mencoba untuk melihat seperti apa pengawasan pengeluaran barang pada toko bebas bea dalam kota (duty free shop) dalam upaya mengamankan penerimaan pajak di Kantor Pengawasan dan Pelayanan Bea dan Cukai Tipe Madya Pabean A Jakarta.

\section{LITERATUR REVIEW}

Diskusi tentang pengawasan pengeluaran barang pada toko bebas bea dalam kota. Kebijakan publik menurut Dye (Deddy Mulyadi, 2015:36), "Kebijakan publik adalah segala sesuatu yang dikerjakan dan yang tidak dikerjakan oleh pemerintah", adapun tujuan dari dibuatkan kebijakan publik adalah untuk memecahkan masalah atau mencari solusi alternatif dari masalah yang menjadi isu bersama yang berkembang di masyarakat. Suatu kebijakan publik bukan hanya proses formulasi dan melegitimasi kebijakan saja, akan tetapi terkait dengan implementasi dan evaluasi kebijakan publik. Sebaik apapun kebijakan publik yang dibuat jika tidak diimplementasikan dengan baik, maka kebijakan tersebut tidak akan berdampak kepada kepentingan masyarakat.

\subsection{Aspek-Aspek Kepabeanan}

Menurut Purwito (2013:28), aspek kepabeanan berkaitan erat dengan sumber daya manusia moral dan digabungkan dengan tujuan organisasi kepabeanan, yang bersifat universal dan terkait dengan konvensi internasional, perjanjian multilateral dan bilateral. Sesuai dengan jiwa perpajakan, aspek kepabeanan terdiri sebagai berikut:

1. Aspek Keadilan adalah aspek ini kewajiban kepabeanan hanya kepada anggota masyarakat yang melakukan kegiatan kepabeanan dan terhadap mereka diperlakukan sama dalam hal dan kondisi yang sama (nondiscriminative). Aspek ini melindungi semua yang melakukan pengguna jasa kepabeanan seperti: importir, eksportir, perusahaan pengurusan jasa kepabeanan (PPJK), forwarder (jasa pengiriman), pengangkut, masing-masing mempunyai hak yang sama dalam pelayanan, kewajiban, dan tanggungjawab. 
2. Pemberian Insentif Terutama bagi investor dan produsen. Insentif tersebut misalnya TPB, Gudang Berikat, yang diberikan pembebasan dan atau keringanan atas impor mesin dan bahan baku dalam rangka ekspor dan pemberian persetujuan impor barang sebelum pelunasan bea masuk dilakukan (prenotification). Meskipun sifatnya bertahap dan sementara waktu, tetapi diharapkan akan dapat memberikan manfaat dan mendukung petumbuhan perekonomian nasional.

3. Netralitas adalah tidak ada diskriminasi dalam pelayanan kepabeanan dan dalam pemungutan bea masuk untuk menghindari distorsi yang dapat mengganggu perekonomian nasional.

4. Kelayakan Administrasi adalah administrasi kepabeanan dilaksanakan secara tertib, terkendali, sederhana, serta transparan. Tertib administrasi berdampak atas pengurangan penyimpanganpenyimpangan yang kemungkinan akan terjadi dan beresiko melalui peraturan yang jelas dan penegakan hukum. Pengendalian, Pengawasan, pemantauan, dan evaluasi atas apa yang terjadi di lapangan dapat diketahui dengancepat dari bidang administrasi. Dengan kata lain, bahwa administrasi tersebut dapat dikelola danmerupakan sarana pengawasan yang baik. Penerapan pengawasan disertai sanksi atas pelanggaran peraturan perundang-undangan kepabeanan. Praktik Kepabeanan internasional, sebagaimana diatur di dalam persetujuan perdagangan internasional, seperti dalam World Trade Organization atau di dalam ketentuan/peraturan yang diterbitkan oleh World Customs Organization.

\subsection{Pengertian Kepabeanan}

Kebijakan-kebijakan yang menjadi tanggung jawab kepabeanan menurut Purwito, (2013: 36): Untuk diawasi tidak terlepas dari peraturan-peraturan instansi-instansi teknis seperti:

1. Departemen-departemen Perdagangan

2. Kesehatan

3. Pertanian

4. Kebudayaan

5. Pertahanan dan Informasi dan Kejaksaan Agung

Dasar institusi kepabeanan di dalamnya terdapat peraturan atau kebijakan masing-masing Departemen teknik. Kepabeanan atau Customs (Inggris) atau Douane (Perancis) adalah instansi yang bertanggung-jawab atas pengawasan pelaksanaan administrasi penerimaan atau pendapatan negara dalam bentuk bea masuk, cukai, pajak pertambahan nilai atau PPN (value added tax/VAT), pajak barang mewah dan pajak pengahasilan dalam rangka impor Pasal 22 Undang-Undang Kepabeanan serta bea keluar yang mengatur mengenai pentarifan atas barang sesuai dengan klasifikasinya.

Undang-undang kepabeanan memberikan pengertian mengenai kepabeanan yang telah dirangkum oleh Purwito, (2013: 37) sebagai berikut, kepabeanan adalah segala sesuatu yang berhubungan dengan pengawasan atas lalu lintas barang yang masuk dan keluar daerah pabean dan pemungutan bea masuk.Berdasarkan pengertian menurut para ahli diatas peneliti dapat menyimpulkan bahwa pajak kendaraan bermotor adalah Pajak yang dikenakan atas kepemilikan atau penguasaan kendaraan bermotor baik orang pribadi maupun badan yang memiliki atau menguasai kendaraan bermotor tersebut.

\subsection{Pengawasan Kepabeanan}

Secara bahasa, pengertian pengawasan menurut kamus lengkap bahasa Indonesia terbitan Balai Pustaka (2005) adalah penilikan atau penjagaan. Sedangkan menurut Adrian Sutedi (2012:58-59) pengawasan adalah suatu kegiatan untuk menjamin atau menjaga agar rencana dapat diwujudkan dengan efektif. Masing - masing organisasi mempunyai rencana untuk mencapai tujuan yang telah ditetapkan. Untuk menjaga agar organisasi itu dapat mencapai tujuannya, mutlak diperlukan pengawasan.

Pengertian pengawasan pabean sebagaimana dimaksud pada Deklarasi Colombus adalah tindakan yang dilakukan pabean untuk memastikan kepatuhan terhadap undang-undang pabean (Customs control means measures applied by the customs to ensure compliance with customs law). Selanjutnya tujuan pengawasan pabean. Menurut Collin Vassarotti adalah memastikan semua pergerakan barang, kapal, pesawat terbang, kendaraan, dan orang-orang yang melintasi perbatasan negara berjalan dalam kerangka hukum, peraturan, dan prosedur pabean yang ditetapkan (Eddhi Sutarto, 2010:90).

Menurut Bambang Semedi (2013:3-4), Setiap administrasi pabean harus melakukan kegiatan pengawasan. Kegiatan pengawasan pabean meliputi seluruh pelaksanaan wewenang yang dimiliki oleh petugas pabean dalam perundang-undangannya yaitu memeriksa: kapal, barang, penumpang, dokumen, 
pembukuan, melakukan penyitaan, penangkapan, penyegelan, dan lain-lain. Dalam modul pencegahan pelanggaran kepabeanan yang dibuat oleh WCO (World Customs Organization) disebutkan bahwa pengawasan pabean adalah salah satu metode untuk mencegah dan mendeteksi pelanggaran kepabeanan. Berdasarkan modul WCO tersebut dinyatakan bahwa pengawasan Bea Cukai yang mampu mendukung pendeteksian dan pencegahan penyelundupan paling tidak harus mencakup kegiatan : penelitian dokumen, pemeriksaan fisik, dan audit pasca impor. Di samping tiga kegiatan itu, patroli juga merupakan pengawasan Bea Cukai untuk mencegah penyelundupan.

Mengenai pemahaman pengawasan pabean Eddhi Sutarto, (2010: 91) menegaskan: Bahwa semua barang, termasuk sarana transportasi yang memasuki atau meninggalkan daerah pabean, tanpa memperhatikan terutang bea dan pajak atau tidak, harus berada dalam pengawasan pabean. Namun, pengawasan pabean tersebut harus dibatasi pada hal-hal yang dianggap perlu untuk memastikan dipatuhinya undang-undang pabean. Di dalam menerapkan pengawasan pabean harus menggunakan manajemen risiko.

Pabean dalam melaksanakan pengawasan harus menggunakan analisis risiko untuk menentukan orang dan barang, termasuk sarana transportasi, yang perlu diperiksa dan seberapa jauh tingkat pemeriksaannya. Pabean harus mengadopsi strategi pengukuran kepatuhan untuk mendukung pelaksanaan manajemen risiko. Pengukuran tersebut digunakan untuk bahan penetapan profil yang berisi himpunan data.

Untuk terciptanya optimalisasi hasil pengawasan pabean, dilakukan administrasi pabean yang mengusahakan kerja sama dengan administrasi pabean lain dan berusaha menghasilkan kesepakatan bantuan administratif yang saling menguntungkan untuk meningkatkan pengawasan pabean. Demikian juga kerja sama dilakukan dengan dunia usaha dan berusaha menghasilkan nota kesepahaman (MoU) untuk meningkatkan pengawasan pabean.

Teknologi informasi dan perdagangan secara elektronik sangat mendukung untuk meningkatkan pengawasan pabean termasuk evaluasi sistem komersial dari pengusaha apabila sistem tersebut mempunyai dampak pada kegiatan pabean dalam memastikan kepatuhan terhadap persyaratan pabean. Pemeriksaan Pabean adalah untuk memperoleh data dan penilaian yang tepat mengenai pemberitahuan pabean yang diajukan terhadap barang impor dilakukan. Pemeriksaan pabean tersebut dalam bentuk penelitian terhadap dokumen dan pemeriksaan atas fisik barang. Pemeriksaan pabean tersebut dilakukan secara selektif berdasarkan analisis manajemen risiko.

Eddhi Sutarto, (2010: 92) mengungkapkan atas dasar: Kewenangan pejabat pabean untuk melakukan pemeriksaan pabean atas barang impor-ekspor diatur dalam Undang-undang Nomor 17 Tahun 2006. Hal ini diartikan bahwa kewenangan pejabat pabean (bea dan cukai) dalam melakukan pemeriksaannya pabean merupakan kewenangan berdasarkan ketentuan hukum positif yang berlaku, yakni kewenangan yang diberikan oleh Undang-undang. Pemeriksaan pabean dalam bentuk penelitian terhadap dokumen dan pemeriksaan atas fisik barang dilakukan untuk memperoleh data dan penilaian yang tepat mengenai pemberitahuan pabean.

Pemeriksaan pabean tersebut pada dasarnya dilakukan dalam daerah pabean oleh pejabat bea dan cukai secara selektif dengan mempertimbangakan risiko yang melekat pada barang dan importir. Namun, dengan mempertimbangkan kelancaran arus barang dan/atau pengamanan penerimaan negara, dapat dilakukan pelaksanaan pemeriksaan pabean di luar daerah pabean oleh pejabat bea dan cukai atau pihak lain yang bertindak untuk dan atas nama Direktorat Jenderal Bea dan Cukai.

Penelitian dokumen sebagaimana dimaksud pada pemeriksaan pabean adalah kegiatan yang dilakukan oleh pejabat bea dan cukai dan/atau sistem komputer untuk memastikan bahwa pemberitahuan dibuat dengan lengkap dan benar. Pejabat pemeriksa dokumen tersebut adalah pejabat bea dan cukai yang berwenang untuk melakukan penelitian dan penetapan atas data pemberitahuan pabean. Penelitian dokumen yang dilakukan oleh pejabat pemeriksa dokumen dan/atau sistem computer pelayanan bertujuan:

1. Untuk memastikan bahwa pemberitahuan pabean diberitahukan dengan benar, dan dokumen pelengkap pabean yang diwajibkan telah sesuai dengan yang telah ditentukan. Penelitian ini dilakukan oleh pejabat pemeriksa dokumen. 
2. Untuk memastikan bahwa pengisian pemberitahuan pabean yang telah disampaikan telah lengkap dan benar. Penelitian ini dilakukan melalui sistem komputer pelayanan.

Penelitian berdasarkan sistem komputer ditindaklanjuti dengan penelitian yang dilakukan pejabat pemeriksa dokumen berdasarkan data yang disajikan oleh sistem komputer pelayanan. Berdasarkan hasil penelitian tersebut, pejabat pemeriksa dokumen melakukan penetapan. Hal ini artinya tanggung jawab hukum pemeriksa dokumen terbatas pada penetapan yang dibuatnya.

Pemeriksaan fisik dalam barang impor dan ekspor adalah kegiatan yang dilakukan pejabat pabean (bea dan cukai) pemeriksaan barang untuk mengetahui jumlah dan jenis barang impor yang diperiksa guna keperluan pengklasifikasian dan penetapan nilai pabean. Pelaksanaan pemeriksaan fisik barang impor dilakukan oleh pejabat pemeriksa fisik berdasarkan instruksi pemeriksaan yang diterbitkan oleh pejabat bea dan cukai atau sistem komputer pelayanan, dan atas pemeriksaan fisik dimaksud, importir atau kuasanya mendapat pemberitahuanpemeriksaan fisik dari pejabat bea dan cukai atau sistem komputer pelayanan.

Pada prinsipnya pejabat bea dan cukai memiliki wewenang berdasarkan undang-undang kepabeanan untuk melakukan pemeriksaan pabean atas barang impor atau barang ekspor setelah pemberitahuan pabean diserahkan. Hal ini diartikan bahwa jika pabean memutuskan bahwa barang yang diberitahukan harus diperiksa, pemeriksaan tersebut harus dilakukan sesegera mungkin setelah pemberitahuan barang di daftarkan.

Pejabat Bea dan Cukai berwenang meminta importir, eksportir, pengangkut, pengusaha tempat penimbunan sementara, pengusaha tempat penimbunan berikat, atau yang mewakilinya menyerahkan barang untuk diperiksa, membuka sarana pengangkut atau bagianya, dan membuka setiap bungkusan atau pengemas yang akan diperiksa. Jika permintaan tidak dipenuhi:

1. Pejabat Bea dan Cukai berwenang melakukan tindakan pemeriksaan atas risiko dan biaya yang bersangkutan; dan

2. Yang bersangkutan dikenai sanksi administrasi berupa denda sebesar Rp.25.000.000,00.

Salah satu bentuk pemeriksaan fisik menurut Eddhi Sutarto, (2010: 94) adalah: Pemeriksaan Jabatan, yaitu pemeriksaan yang dilakukan oleh pejabat bea dan cukai karena kewenangan yang dimilikinya berdasarkan ketentuan Undang-undang kepabeanan dalam rangka pengawasan. Oleh karena itu, untuk kepentingan pengawasan, pejabat bea dan cukai berwenang melakukan pemeriksaan karena jabatan atas fisik barang impor atau barang ekspor sebelum atau sesudah pemberitahuan pabean disampaikan.

Pemeriksaa Fisik terhadap barang tertentu dalam perundang-undangan yang berlaku yaitu Undangundang Nomor 17 Tahun 2006 tentang kepabeanan secara eksplit disebutkan bahwa kewenangan Ditjen Bea dan Cukai adalah melakukan pengawasan atas lalu lintas barang yang masuk atau keluar daerah pabean. Namun mengingat letak geografis Indonesia, pengawasan dan pemeriksaan pada prinsipnya dilakukan untuk menghindari penyelundupan dengan modus pengangkutan antar pulau, khususnya untuk barang tertentu.

Secara implisit Eddhi Sutarto, (2010: 95) mengatakan bahwa: Pengawasan pengangkutan barang tertentu dalam daerah pabean merupakan perpanjang kewenangan atau bagian yang tidak terpisahkan dari kewenangan pabean sebagai salah satu instansi pengawas perbatasan.

Selain itu, pengertian audit kepabeanan dalam Pasal 1 angka 20 Undang-Undang Nomor 17 tahun 2006 tentang Perubahan Atas Undang-Undang Nomor 10 Tahun 1995 tentang Kepabeanan adalah kegiatan pemeriksaan laporan keuangan, buku, catatan dan dokumen yang menjadi bukti dasar pembukuan, surat yang berkaitan dengan kegiatan di bidang kepabeanan, dan/atau sediaan barang dalam rangka pelaksanaan ketentuan peraturan perundang-undangan di bidang kepabenan. Jenis audit dibedakan dalam tiga kelompok, yakni: (1) audit umum yaitu audit kepabeanan yang memiliki ruang lingkup pemeriksaan secara lengkap dan menyeluruh terhadap pemenuhan ketentuan kepabeanan, (2) audit khusus yaitu audit kepabeanan yang memiliki ruang lingkup pemeriksaan terhadap pemenuhan kewajiban kepabeanan tertentu, (3) audit investigasi yaitu audit kepabeanan yang dilakukan untuk menyelidiki dugaan tindak pidana kepabeanan. 
Berdasarkan Bahan Ajar II Fasilitas Pembebasan atau Keringanan Bea Masuk dan Fasilitas Tempat Penimbunan Berikat, Modul Pembelajaran Pusdiklat Bea dan Cukai Tahun 2011 (Ahmad Dimyati 2011: 27). Toko Bebas Bea adalah Tempat Penimbunan Berikat untuk menimbu $\mathrm{n}$ barang asal impor dan/atau barang asal Daerah Pabean untuk dijual kepada orang tertentu. Di dalam Toko Bebas Bea dilakukan penyelenggaraan dan pengusahaan Toko Bebas Bea. Penyelenggaraan Toko Bebas Bea dan Pengusahaan Toko Bebas Bea dilakukan oleh penyelenggara Toko Bebas Bea sekaligus pengusaha Toko Bebas Bea yang berbadan hukum Indonesia dan berkedudukan di Indonesia.

\section{Analisis Pengawasan Pengeluaran Barang Pada Toko Bebas Bea Dalam Kota (Duty Free Shop) Dalam Upaya Mengamankan Penerimaan Pajak (Studi Kasus PT SJ Indonesia Tahun 2017)}

Fasilitas Toko Bebas Bea merupakan salah satu fasilitas kepabeanan berupa Tempat Penimbunan Berikat (TPB) yang diberikan oleh Direktorat Jenderal Bea dan Cukai (DJBC). Bentuk pemberian fasilitas tersebut adalah berupa penangguhan bea masuk, pembebasan cukai dan tidak dipungut pajak dalam rangka impor (PDRI). Agar fasilitas tersebut digunakan sesuai dengan koridor peruntukannya sudah selayaknya DJBC mengedepankan fungsi pengawasan tanpa mengabaikan fungsi pelayanannya. Karena pada hakekatnya masih terdapat hak - hak negara yang harus diawasi penggunannya agar tidak disalahgunakan.

Mengacu pada Peraturan Menteri Keuangan Nomor 207/PMK.04/2017 maupun Peraturan Direktur Jenderal Bea dan Cukai PER-01/BC/2018 tentang Toko Bebas Bea. Pengeluaran berupa pembelian barang pada toko bebas bea dalam kota hanya diperuntukan bagi orang tertentu yang berhak, yaitu:

1. Anggota korps diplomatik yang bertugas di Indonesia beserta keluarganya yang berdomisili di Indonesia berikut lembaga diplomatik.

2. Pejabat/tenaga ahli yang bekerja pada badan internasional di Indonesia yang memperoleh kekebalan diplomatik beserta keluarganya .

3. Orang yang akan ke luar daerah pabean (penyerahan barang di TBB yg sama yang berlokasi di bandara/pelabuhan utama)

Untuk pengeluaran/pembelian barang BKC (Barang Kena Cukai) yang dilakukan Anggota korps diplomatik sebagaimana dijelaskan pada poin a dan pejabat/tenaga ahli sebagaimana dijelaskan pada poin $\mathrm{b}$ menggunakan dokumen berupa Kartu Kendali. Namun jika pengeluaran/pembelian berupa barang non BKC maka hanya cukup menunjukan identitas sebagai anggota korps diplomatik atau pejabat/tenaga ahli yang bekerja pada badan internasional di Indonesia.

Dalam hal barang yang dibeli dl Toko Bebas Bea oleh orang tertentu yang berhak sebagaimana dimaksud poin a yaitu anggota korps diploimatik merupakan BKC (Barang Kena Cukai) pembelian dibatasi dalam jumlah yang ditetapkan oleh instansi teknis terkait berdasarkan asas timbal balik dengan mendapatkan pembebasan cukai.

Dalam hal barang yang dibeli di Toko Bebas Bea oleh orang tertentu yang berhak sebagaimana dimaksud pada poin b yaitu pejabat/tenaga ahli yang bekerja pada badan internasional di Indonesia merupakan barang kena cukai, pembelian dibatasi berdasarkan rekomendasi dari instansi teknis terkait dalam jumlah paling banyak:

1. 10 (sepuluh) liter minuman mengandung etil alkohol per orang dewasa per bulan; dan/ atau

2. 300 (tiga ratus) batang sigaret atau 100 (seratus) batang cerutu atau 500 (lima ratus) gram tembakau

iris/hasil tembakau lainnya per orang dewasa per bulan atau dalam hal lebih dari satu jenis hasil

tembakau, setara dengan perbandingan jumlah per jenis hasil tembakau tersebut, diberikan pembebasan cukai.

Pembelian barang di Toko Bebas Bea oleh lembaga diplomatik dapat dilakukan dengan persetujuan Kepala Kantor Wilayah atau KPU dengan ketentuan:

1. Berdasarkan permohonan yang disampaikan oleh pimpinan lembaga diplomatik;

2. Untuk kepentingan khusus seperti perayaan hari kemerdekaan negara yang bersangkutan dan perayaan hari besar tertentu;

3. Telah direkomendasikan oleh instansi teknis terkait;

4. Dalam jumlah sesuai dengan yang ditetapkan olehinstansi teknis terkait berdasarkan asas timbal balik; dan

5. Mendapatkan pembebasan cukai 
Penyerahan barang yang dibeli oleh orang yang akan ke luar dari Daerah dilakukan dengan menunjukkan paspor dan tanda bukti penumpang (boarding pass).

Pembelian barang oleh orang yang akan ke luar dari Daerah Pabean sebagaimana dapat dimasukkan kembali ke Toko Bebas Bea dalam hal:

1. Tidak diambil oleh pemiliknya di terminal keberangkatan;

2. Retur

Selain hal diatas Pengeluaran barang dari Toko Bebas Bea dapat dilakukan dengan tujuan ke gudang berikat, ke tempat lain dalam Daerah Pabean, Toko Bebas Bea lainnya, diekspor kembali, dan/atau dimusnahkan di bawah pengawasan Pejabat Bea dan Cukai.

Mengenai pemahaman pengawasan pabean Eddhi Sutarto, (2010:91) menegaskan: Bahwa semua barang, termasuk sarana transportasi yang memasuki atau meninggalkan daerah pabean, tanpa memperhatikan terutang bea dan pajak atau tidak, harus berada dalam pengawasan pabean. Namun, pengawasan pabean tersebut harus dibatasi pada hal-hal yang dianggap perlu untuk memastikan dipatuhinya Undang-undang pabean. Di dalam menerapkan pengawasan pabean, pabean harus menggunakan manajemen risiko.

Pabean dalam melaksanakan pengawasan harus menggunakan analisis risiko untuk menentukan orang dan barang, termasuk sarana transportasi, yang perlu diperiksa dan seberapa jauh tingkat pemeriksaannya. Pabean harus mengadopsi strategi pengukuran kepatuhan untuk mendukung pelaksanaan manajemen risiko. Pengukuran tersebut digunakan untuk bahan penetapan profil yang berisi himpunan data. Disebutkan bahwa pengawasan pabean adalah salah satu metode untuk mencegah dan mendeteksi pelanggaran kepabeanan. Berdasarkan modul WCO tersebut dinyatakan bahwa pengawasan Bea Cukai yang mampu mendukung pendeteksian dan pencegahan penyelundupan paling tidak harus mencakup kegiatan: penelitian dokumen, pemeriksaan fisik, dan audit pasca impor

\subsection{Penelitian Dokumen}

Dokumen pengeluaran barang pada toko bebas bea dalam kota (Duty Free Shop) PT SJ Indonesia secara garis besar dapat di kategorikan beberapa dokumen sebagai berikut berdasar peraturan DJBC No. Per-19/BC/2013 :

1. Kartu Kendali;

Untuk pengeluaran / pembelian barang BKC (Barang Kena Cukai) yang dilakukan Anggota korps diplomatik atau pejabat / tenaga ahli.

2. CK-5;

Pengangkutan BKC yang belum dilunasi cukainya, baik dalam keadaan setelah dikemas dalam kemasan untuk penjualan eceran maupun dalam keadaan curah atau dikemas dalam kemasan bukan untuk penjualan eceran wajib dilindungi oleh dokumen cukai.

3. BC 2.7;

Merupakan salah satu dokumen pemberitahuan pabean, yaitu pemberitahuan pengeluaran barang untuk diangkut dari Tempat Penimbunan Berikat (TPB) ke Tempat Penimbunan Berikat (TPB) lainnya.

4. BC 3.0;

\section{5. $\mathrm{BC} 4.1$}

Merupakan dokumen pemberitahuan pabean, yaitu untuk diekspor kembali.

Merupakan dokumen pemberitahuan pabean, yaitu untuk Pengeluaran Kembali Barang Asal Tempat Lain Dalam Daerah Pabean dari Tempat Penimbunan Berikat (eks lokal).

Penulis mencoba mengkaji alur pengeluaran barang menggunakan Kartu Kendali (KK) berdasarkan Peraturan DJBC No Per 19 / BC /2013. 
Gambar IV.4 Alur Praktik Penggunaan Kartu Kendali Di TBB dalam kota secara umum

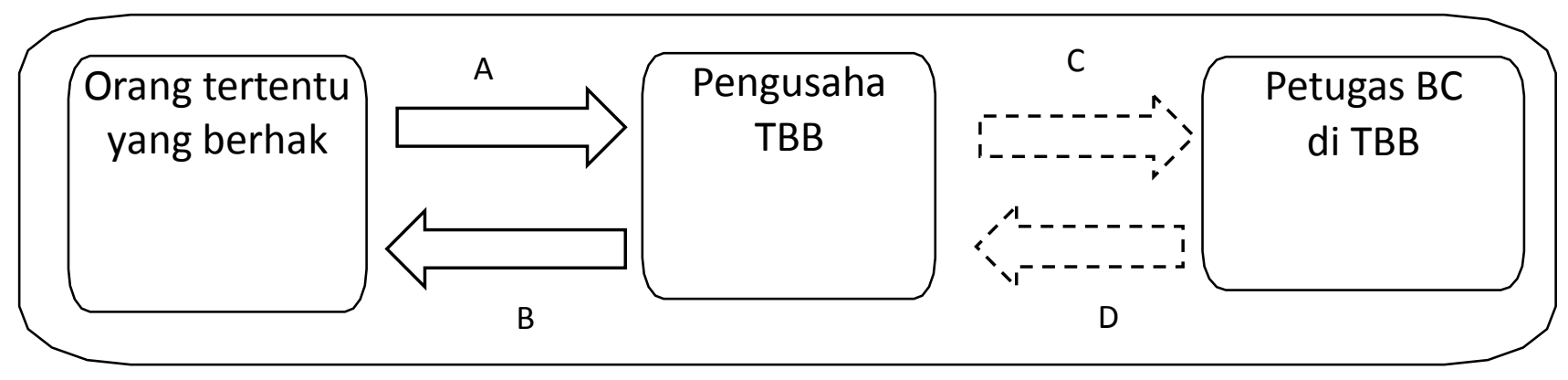

Sumber: Diolah Penulis menurut Per-19/BC/2013

Penjelasan:

A. 1. Orang tertentu yang berhak mendatangi TBB dengan membawa KK asli yang masih berlaku dan menunjukkannya kepada Pengusaha TBB (Pasal 16 PER-19/BC/2013).

2. Pengusaha TBB menerima KK asli, meneliti dan mendata orang yang membeli barang di TBB yang diusahakannya (Pasal 25 ayat (1) PER-19/BC/2013);

2.1. Penelitian dilakukan dengan memastikan bahwa orang yang membeli barang di TBB adalah orang tertentu yang berhak, yang meliputi:

a. memastikan kebenaran kartu kendali dengan cara mencocokkan dengan data yang tersedia atau database kartu kendali pada sistem komputer di TBB;

b. memastikan bahwa pembelian barang dilakukan oleh orang yang tercantum dalam kartu kendali/tidak diwakilkan; dan

c. memastikan bahwa pembelian barang kena cukai tidak melebihi batasan yang diperkenankan;

(Pasal 25 ayat (2) dan ayat (4) huruf a PER-19/BC/2013).

2.2. Pendataan meliputi kegiatan:

a. mencatat data identitas orang yang membeli barang di TBB, paling sedikit meliputi:

- nama, warga negara, dan tanggal lahir;

- nomor kartu kendali;

- jumlah dan jenis barang yang dibeli; dan

- waktu transaksi.

b. melakukan pemotongan kuota pada kartu kendali;

[Pasal 25 ayat (5) huruf a dan b PER-19/BC/2013].

2.3. Pengusaha TBB melakukan perekaman ke dalam sistem Teknologi informasi pengelolaan pemasukan dan pengeluaran barang /IT Inventory (Pasal 25 ayat (5) PER-19/BC/2013).

B. 1. Pengusaha TBB mengembalikan KK asli yang telah dilakukan pemotongan kuota dengan pembubuhan tanda paraf dan/atau stempel perusahaan kepada pembeli, membuat faktur penjualan/invoice/surat jalan dan menyerahkan BKC kepada pembeli.

2. Pembeli menerima KK asli yang telah dilakukan pemotongan, faktur penjualan/invoice/surat jalan dan BKC dari Pengusaha TBB dan meninggalkan lokasi TBB.

C. Setelah pembeli meninggalkan lokasi, Pengusaha TBB mengajukan CK-5 dalam rangkap 3 (tiga) kepada petugas Bea dan Cukai di TBB dengan melampirkan dokumen pendukung berupa fotokopi KK yang telah dilakukan pemotongan kuota dan sebagainya:

- rangkap ke-1 (satu) untuk dokumen pelindung/pengangkutan BKC;

- $\quad$ rangkap ke-2 (dua) untuk pejabat bea dan cukai yang mengawasi;

- rangkap ke-3 (tiga) untuk pengusaha TBB;

(Pasal 31 PER-19/BC/2013 dan Pasal 9 ayat (2) huruf f PER-2/BC/2015).

D. Petugas Bea dan Cukai di TBB menandatangani CK-5, melakukan pengarsipan CK-5 rangkap ke-2 dan menyerahkan CK-5 rangkap ke-1 dan ke-3 beserta dokumen pendukung kepada Pengusaha TBB.

Dari uraian diatas, penulis menyimpulkan bahwa penelitian dokumen untuk pengeluaran barang dari Toko Bebas Bea Dalam Kota menggunakan Kartu Kendali dititik beratkan pada Pengusaha TBB. 
Pengeluaran barang dari Toko Bebas Bea Dalam Kota selain dilakukan oleh dilakukan Anggota korps diplomatik atau pejabat / tenaga ahli juga dapat dilakukan oleh orang yang akan ke luar daerah pabean (penyerahan barang di TBB yg sama yang berlokasi di bandara/pelabuhan utama ).Pada PT SJ Indonesia pengeluaran tersebut menggunakan dokumen pabean BC 2.7. Dokumen tersebut merupakan dokumen pengeluaran barang untuk diangkut dari Tempat Penimbunan Berikat (TPB) ke Tempat Penimbunan Berikat (TPB) lainnya. TPB yang dimaksud dalam hal ini adalah Toko Bebas Bea (TBB).

Dokumen pengeluaran barang BC 2.7 tidak hanya digunakan untuk pembelian oleh orang yang akan ke luar daerah pabean (penyerahan barang di TBB yg sama yang berlokasi di bandara/pelabuhan utama). Namun juga digunakan dalam hal pengeluaran barang seperti ke antar TBB lainnya. Perbedaanya untuk pengeluaran barang ke TBB lainnya, perusahaan harus mengajukan izin dahulu ke kantor yang mengawasi dalam hal ini Kepala Kantor Pengawasan dan Pelayanan Bea dan Cukai Tipe Madya Pabean A Jakarta. Dalam hal pengeluaran barang dari Toko Bebas Bea dengan tujuan diekspor kembali berlaku ketentuan tatalaksana kepabeanan di bidang ekspor. Dokumen pabean yang digunakan yaitu BC 3.0.

\subsection{Pemeriksaan Fisik}

Eddhi Sutarto, (2010:92) mengungkapkan atas dasar: Kewenangan pejabat pabean untuk melakukan pemeriksaan pabean atas barang impor-ekspor diatur dalam Undang-undang Nomor 17 Tahun 2006. Hal ini diartikan bahwa kewenangan pejabat pabean (bea dan cukai) dalam melakukan pemeriksaannya pabean merupakan kewenangan berdasarkan ketentuan hukum positif yang berlaku, yakni kewenangan yang diberikan oleh Undang-undang. Pemeriksaan pabean dalam bentuk penelitian terhadap dokumen dan pemeriksaan atas fisik barang dilakukan untuk memperoleh data dan penilaian yang tepat mengenai pemberitahuan pabean.

Pemeriksaan fisik dalam barang impor dan ekspor adalah kegiatan yang dilakukan pejabat pabean (bea dan cukai) pemeriksaan barang untuk mengetahui jumlah dan jenis barang impor yang diperiksa guna keperluan pengklasifikasian dan penetapan nilai pabean. Pelaksanaan pemeriksaan fisik barang impor dilakukan oleh pejabat pemeriksa fisik berdasarkan instruksi pemeriksaan yang diterbitkan oleh pejabat bea dan cukai atau sistem komputer pelayanan, dan atas pemeriksaan fisik dimaksud, importir atau kuasanya mendapat pemberitahuanpemeriksaan fisik dari pejabat bea dan cukai atau sistem komputer pelayanan.

Pada prinsipnya pejabat bea dan cukai memiliki wewenang berdasarkan undang-undang kepabeanan untuk melakukan pemeriksaan pabean atas barang impor atau barang ekspor setelah pemberitahuan pabean diserahkan. Hal ini diartikan bahwa jika pabean memutuskan bahwa barang yang diberitahukan harus diperiksa.

Salah satu bentuk pemeriksaan fisik menurut Eddhi Sutarto, (2010:94) adalah: Pemeriksaan jabatan, yaitu pemeriksaan yang dilakukan oleh pejabat bea dan cukai karena kewenangan yang dimilikinya berdasarkan ketentuan Undang-undang kepabeanan dalam rangka pengawasan. Oleh karena itu,untuk kepentingan pengawasan, Pejabat Bea dan Cukai berwenang melakukan pemeriksaan karena jabatan atas fisik barang impor atau barang ekspor sebelum atau sesudah pemberitahuan pabean disampaikan.

PT SJ Indonesia merupakan satu - satunya TBB yang berada dalam pengawasan Kantor Bea Cukai Jakarta yang memiliki kategori barang yang dijual sangat bervariatif, dibandingkan dengan TBB lainnya yang hanya menjual BKC. Luasnya area TBB, cukup tingginya aktivitas keluar masuk barang, terbatasnya jumlah pejabat bea cukai (hanggar) yang mengawasi langsung, dan jam operasional yang lebih lama mengakibatkan pemeriksaan fisik terhadap pengeluaran pada TBB dalam kota harus dilakukan berdasarkan manajemen resiko.

Mengenai pemahaman pengawasan pabean Eddhi Sutarto, (2010:91) menegaskan: Bahwa semua barang, termasuk sarana transportasi yang memasuki atau meninggalkan daerah pabean, tanpa memperhatikan terutang bea dan pajak atau tidak, harus berada dalam pengawasan pabean. Namun, pengawasan pabean tersebut harus dibatasi pada hal-hal yang dianggap perlu untuk memastikan dipatuhinya Undang-undang pabean. Di dalam menerapkan pengawasan pabean, harus menggunakan manajemen risiko.

Pejabat bea cukai (hanggar) yang mengawasi langsung melakukan pemeriksaan fisik pada pengeluaran barang dari TBB dalam kota PT SJ Indonesia lebih menfokuskan pemeriksaan fisik barang atas pengeluaran 
barang menggunakan dokumen pabean BC 2.7. Pemeriksaan barang untuk mengetahui jumlah dan jenis barang apakah sesuai dengan pemberitahuan pabean yang diberitahukan.

Pemeriksaan fisik barang dilanjutkan dengan pengawasan stuffing (pemuatan) pada sarana pengangkut yang membawa barang - barang dari TBB. Selanjutnya dilakukan penyegelan terhadap sarana pengangkut. Hal ini untuk memastikan bahwa barang tersebut benar - benar telah sampai tujuan sehingga hak - hak negara terhadap pungutan negara/penerimaan pajak yang ditangguhkan dapat dipertanggungjawabkan.

\subsection{Audit Kepabeanan (Pengawasan Tidak Langsung)}

Audit Kepabeanan adalah kegiatan pemeriksaan laporan keuangan, buku, catatan dan dokumen yang menjadi bukti dasar pembukuan dan surat yang berkaitan dengan kegiatan usaha, termasuk data elektronik, serta surat yang berkaitan dengan kegiatan di bidang kepabeanan, dan/atau sediaan barang dalam rangka pelaksanaan ketentuan perundang-undangan di bidang kepabeanan.

Audit kepabeanan dilakukan berupa serangkaian kegiatan pemeriksaan buku, catatan dan dokumen serta persediaan barang perusahaan dalam rangka pengawasan terhadap pemenuhan ketentuan di bidang kepabeanan dan cukai. Pelaksanaan ketentuan lainnya dibebankan kepada Dirjen Bea dan Cukai. Audit kepabeanan bermanfaat dalam proses pemeriksaan bidang perpajakan dengan tujuan mengamankan hak hak keuangan negara.

Pada tahun 2017, PT SJ Indonesia pernah dilakukan Audit Kepabeanan, namun dilakukan oleh Direktorat Audit Direktorat Jenderal Bea dan Cukai, Kantor Pusat bukan oleh Kantor Pengawasan dan Pelayanan Bea dan Cukai Tipe Madya Pabean A Jakarta.

Instrumen pengawasan tidak langsung lain yang dilakukan oleh Pejabat Bea dan Cukai adalah pengawasan pencacahan (stockopname) sebagaimana menjadi kewajiban pengusaha TBB yang diatur dalam ketentuan. Pengusaha TBB melakukan pencacahan (stockopname) terhadap barang-barangyang mendapat fasilitas kepabeanan, cukai, dan perpajakan, dengan mendapatkan pengawasan dari Kantor Pabean yang mengawasi, paling sedikit 1 (satu) kali dalam kurun waktu 1 (satu) tahun.

Pengusaha TBB juga diwajibkan menyelenggarakan pembukuan mengenai pemasukan dan pengeluaran barang ke dan dari Toko Bebas Bea serta pemindahan barang dalam Toko Bebas Bea berdasarkan prinsipprinsip akuntansi yang berlaku umum di Indonesia, menyimpan dan memelihara dengan baik pada tempat usahanya buku dan catatan serta dokumen yang berkaitan dengan kegiatan usahanya dalam kurun waktu 10 (sepuluh) tahun, dan menyerahkan dokumen yang berkaitan dengan kegiatan Toko Bebas Bea jika dilakukan pemeriksaan oleh Direktorat Jenderal Bea dan Cukai.

Selain itu, pengusaha TBB juga diwajibkan menyampaikan rekapitulasi pemasukan, pengeluaran dan persediaan barang berupa: laporan pemasukan dan pengeluaran barang per dokumen pabean, laporan penjualan barang; dan laporan persediaan barang.

Pejabat Bea dan Cukai di Kantor Pabean melakukan penelitian atas laporan pemasukan dan pengeluaran barang per dokumen pabean, laporan penjualan barang, dan laporan persediaan barang. Dalam hal hasil penelitian menunjukkan adanya selisih lebih maupun selisih kurang, dan/atau barang di Toko Bebas Bea dijual kepada orang yang tidak berhak, Pejabat Bea Dan Cukai melakukan penelitian mendalam.

\section{CONCLUSIONS}

Berdasarkan hasil penelitian, pembahasan, dan interpretasi yang telah diuraikan pada bab-bab sebelumnya, serta dengan mengacu pada teori dan hasil penelitian sebelumnya, maka peneliti dapat menarik kesimpulan tentang Pengawasan Pengeluaran Barang Pada Toko Bebas Bea Dalam Kota (Duty Free Shop) Dalam Upaya Mengamankan Penerimaan Pajak Di Kantor Pengawasan dan Pelayanan Bea dan Cukai Tipe Madya Pabean A Jakarta sebagai berikut:

Pengawasan pengeluaran barang pada toko bebas bea dalam kota (Duty Free Shop) pada PT SJ Indonesia pada tahun 2017 belum optimal karena masih terdapat pelanggaran yang dilakukan oleh pengguna jasa terhadap ketentuan peraturan perundangan kepabeanan. Instrumen penelitian dokumen dan pemeriksaan fisik (pemeriksaan pabean ) yang dilakukan oleh Pejabat Bea dan Cukai masih belum berjalan optimal sehingga Audit Kepabeanan menjadi pintu pengawasan terakhir yang dilakukan oleh Direktorat Jenderal Bea dan Cukai (DJBC) dalam hal pengawasan Toko Bebas Bea. 


\section{REFERENCES}

Departemen Pendidikan Nasional. 2005. Kamus Besar Bahasa Indonesia. Jakarta: Balai Pustaka

Dimyati, Achmad. 2011. Modul Diklat Teknis Substantif Dasar Kepabeanan dan Cukai tentangTeknis Kepabeanan. Jakarta: Badan Pendidikan dan Pelatihan Keuangan, Pusdiklat Bea dan Cukai.

Mulyadi, Dedi.2015. Studi Kebijakan Publik dan Pelayanan Publik: Konsep dan Aplikasi Proses Kebijakan Publik dan Pelayanan Publik. Bandung:Alfabeta.

Purwito, Ali. 2013. Kepabeanan Konsep dan Aplikasi. Jakarta: Samudra Ilmu.

Semedi, Bambang. 2013. Pengawasan Kepabeanan. Jakarta: Badan Pendidikan dan Pelatihan Keuangan, Pusdiklat Bea dan Cukai.

Sutarto, Eddhi. 2010. Rekonstruksi Sistem Hukum Pabean Indonesia. Erlangga:Jakarta.

\section{Dokumen:}

Undang-Undang Nomor 17 Tahun 2006 tentang Perubahan Atas Undang-Undang Nomor 10 Tahun 1995 Tentang Kepabeanan.

Peraturan Pemerintah Nomor 32 Tahun 2009 tentang Tempat Penimbunan Berikat

Peraturan Pemerintah Nomor 85 Tahun 2015 tentang Perubahan Atas Peraturan Pemerintah Nomor 32 Tahun 2009 tentang Tempat Penimbunan Berikat

Peraturan Menteri KeuanganNomor 37/PMK.04/2013 tentang Toko Bebas Bea.

Peraturan Menteri KeuanganNomor 207/PMK.04/2017 tentang Toko Bebas Bea.

Peraturan Menteri Keuangan Nomor 225/PMK.04/2015 tentang Perubahan Atas Peraturan Menteri Keuangan Nomor 139/PMK.04/2007 tentang Pemeriksaan Pabean Di Bidang Impor.

Peraturan DirekturJenderal Bea dan CukaiNomor P-22/BC/2009 tentang Pemberitahuan Pabean Impor

Peraturan DirekturJenderal Bea dan Cukai Nomor 26/BC/2016 tentang Tatalaksana Pengeluaran Barang Impor dari Tempat Penimbunan Berikat ke Tempat Penimbunan Berikat Lain.

Peraturan DirekturJenderal Bea dan Cukai PER-19/BC/2013 tentang Toko Bebas Bea.

Peraturan DirekturJenderal Bea dan Cukai PER-01/BC/2018 tentang Toko Bebas Bea 